Journal of Management and Bussines (JOMB)

Volume 1, Nomor 1, Juni 2019

DOI : https://doi.org/10.31539/jomb.v1i1.684

\title{
ANALISIS NILAI PELANGGAN DAN PENGALAMAN PELANGGAN TERHADAP KEPERCAYAAN PELANGGAN WISATA KULINER SELAMAT TOSERBA SUKABUMI
}

\author{
Nurinda Rahmawati ${ }^{1}$, Asep M. Ramdan ${ }^{2}$, Acep Samsudin ${ }^{3}$ \\ Universitas Muhammadiyah Sukabumi ${ }^{1,2,3}$ \\ Email: nrndrhm@gmail.com ${ }^{1}$
}

\begin{abstract}
ABSTRAK
Tujuan penelitian ini adalah untuk mengetahui nilai pelanggan dan pengalaman pelangganterhadap kepercayaan pelanggan pada Wisata Kuliner Selamat Toserba Sukabumi. Metode penelitian yang digunakan oleh penulis dalam penelitian ini menggunakan metode sistem random sampling dimana penulis menyebarkan kuesioner terhadap 100pelanggan. Teknik analisis yang digunakan penulis adalah menggunakan teknik analisis regresi linear berganda, koefesien korelasi ganda dan koefesien determinasi dan untuk pengujian hipotesis penulis menggunakan uji statistik secara parsial (uji t) dan uji simultan (uji f). Hasil penelitian, menggunakan uji koefesien determinasi menunjukan nilai (Adjuster $\mathrm{R}^{2}$ ) sebesar 0,437 yang berarti pengaruh pengalaman pelanggan terhadap kepercayaan pelanggan adalah $43,7 \%$ dan $56,3 \%$ dipengaruhi oleh faktor lain yang tidak diteliti. Selain itu, pengujian koefesien korelasi ganda menunjukan nilai $\mathrm{R}$ sebesar 0,669 yang berarti terjadi hubungan yang kuat antara pengalaman pelanggan terhadap kepercayaan pelanggan. Simpulan, nilai pelanggan dan pengalaman pelanggan berpengaruh positif dan signifikan secara bersama-sama terhadap kepercayaan pelanggan
\end{abstract}

Kata Kunci : Nilai Pelanggan, Pengalaman Pelanggan, Kepercayaan Pelanggan.

\begin{abstract}
The purpose of this study was to find out customer value and customer experience towards customer trust in the Happy Toserba Sukabumi Culinary Tourism. The research method used by the authors in this study used a system of random sampling where the authors distributed questionnaires to 100 customers. The analysis technique used by the writer is to use multiple linear regression analysis techniques, multiple correlation coefficient and determination coefficient and for hypothesis testing the author uses partial statistical tests ( $t$ test) and simultaneous tests $(f$ test). The results of the study, using the determination coefficient test shows the value (Adjuster R2) of 0.437 which means the influence of customer experience on customer trust is $43.7 \%$ and $56.3 \%$ is influenced by other factors not examined. In addition, testing multiple correlation coefficients shows an $R$ value of 0.669 which means there is a strong relationship between customer experience and customer trust. Conclusions, customer value and customer experience have a positive and significant effect together on customer trust
\end{abstract}

Keywords: Customer Value, Customer Experience, Customer Trust 


\section{PENDAHULUAN}

Topik penelitian mengenai kepercayaan pelanggan, peneliti mengkaji Selama 15 tahun terakhir. Berdasarkan datanya menurut (Ribbink, 2004), (Guenzi, 2009), (Perepelkin, 2011). Badan Ekonomi Kreatif (Bekraf) Republik Indonesia mencatat, subsektor kuliner berkontribusi 41,4\% dari total kontribusi perekonomian kreatif Rp 922 triliun pada 2016. Jumlah tersebut merupakan yang paling tinggi dibandingkan 16 subsektor lain di Bekraf RI. Berdasarkan adanya penelitian mengenai kepercayaan pelanggan pada literatur dengan data dari berbagai industri, serta pada sektor Wisata Kuliner menurut (Salim, 2013), (Salis, 2016), (Febri, 2017), (Kristiana, 2018)

Pada awalnya makanan hanya menjadi salah satu pelengkap kegiatan wisata, namun kemudian berkembang menjadi salah satu bentuk wisata khusus yang disebut dengan istilah wisata kuliner mengingat makanan juga diakui sebagai ekspresif identitas dan budaya. Wisata kuliner pada saat ini sudah menjadi kebutuhan bagi setiap orang yang menginginkan berbagai jenis makanan yang lezat juga unik, khususnya bagi setiap orang pecinta makanan. Bahkan wisata kuliner saat ini sudah menjadi gaya hidup, karena bagi sebagian orang berwisata bukan hanya berjalan-jalan saja tetapi menikmati juga makanan khas daerah-daerah yang dikunjungi.

Permasalahan yang sering dihadapi oleh pedagang Wisata Kuliner terutama dalam terletak pada kepercayaan pelanggan. Sebelum membeli produk pelanggan biasanya memiliki preferensi terhadap produk yang akan mereka pilih baik dari bentuk, rasa maupun banyaknya variant tersebut. Permasalahan yang terjadi pada pelanggan ialah mereka merasa produk yang mereka pesan tidak sesuai dengan informasi pada buku menu dan yang pedagang.

\section{KAJIAN TEORI}

\section{Nilai Pelanggan}

"Value is determined on the customer's terms in the context of his or her unique needs" Robinette dan Brand (2001). Bahwa menciptakan dan memberikan nilai pelanggansuperior kepada high-value customers bisa meningtkatkan sebuah organisasi (value of an organization)." (Tjiptono (2014). Ada 4 (empat) aspek utama yang dapat membentuk sebuah nilai postitif bagi nilai, yaitu:

1. Emotional Value, yaitu utilitas yang berasal dari perasaan atau afektif/emosi positif yang ditimbulkan dari mengkonsumsi produk. 
2. Social value, yaitu utilitas yang didapatkan dari kemampuan produk untuk meningkatkan konsep diri sosial konsumen.

3. Quality / Performance Value, yakni utilitas yang didapatkan dari produk dikarenakan reduksi biaya jangka pendek dan biaya jangka panjang.

4. Price / Value for Money, yakni utilitas yang diperoleh dari persepsi terhadap kualitas dan kinerja yang diharapkan atas produk.

\section{Pengalaman Pelanggan}

Pengalaman otentik yang membuat nilai pribadi menjadikan ketertarikan konsumen pada produk, jasa maupun perusahaan sehingga mempengaruhi bisnis menjadi sukses. Selain itu, Rini (2016) pengalaman pelanggan melibatkan panca indera, hati, pikiran, yang dapat menempatkan pembelian produk atau jasa di antara konteks yang lebih besar dalam kehidupan. Schmitt dalam Salim dan Catherine dan Andreani (2013) menjelaskan bahwa pengalaman pelanggan dapat diukur dengan menggunakan 5 faktor utama yaitu :

1. Sensory Experience. Sense Experience didefinisikan sebagai usaha penciptaan pengalaman yang berkaitan dengan panca indera melalui penglihatan, suara, sentuhan, rasa, dan bau. Di mana digunakan untuk mendiferensiasikan perusahaan dan produknya di market, memotivasi konsumen untuk mau membeli produk tersebut dan menyampaikan value kepada konsumennya.

2. Feel / Affective Experience. Feel Experience adalah strategi dan implementasi untuk memberikan pengaruh merek kepada konsumen melalui komunikasi (iklan), produk (kemasan dan isinya), identitas produk (co-branding), lingkungan, website, orang yang menawarkan produk. Setiap perusahaan harus memiliki pemahaman yang jelas mengenai cara penciptaan perasaan melalui pengalaman konsumsi yang dapat menggerakkan imajinasi konsumen yang diharapkan dapat membuat keputusan untuk membeli. Feel Experience timbul sebagai hasil kontak dan interaksi yang berkembang sepanjang waktu, di mana dapat dilakukan melalui perasaan dan emosi yang ditimbulkan. Selain itu juga dapat ditampilkan melalui ide dan kesenangan serta reputasi akan pelayanan konsumen. Tujuan dari Feel Experience adalah untuk menggerakkan stimulus emosional (events, agents, objects) sebagai bagian dari feel strategies sehingga dapat mempengaruhi emosi dan suasana hati konsumen. 
3. Think / Creative Cognitive Experience. Tujuan dari think marketing adalah membawa pelanggan mampu berfikir lebih mendalam dan kreatif sehingga memberikan opini yang bagus terhadap produk dan service perusahaan.

4. Act / Physical Experience and Entitle Lifestyle. Tujuannya adalah mendorong konsumen sehingga tertarik dan berpikir secara kreatif sehingga mungkin dapat menghasilkan evaluasi kembali mengenai perusahaan dan merek tersebut.

5. Relate / Social Identity Experience. Relate Experience merupakan gabungan dari keempat aspek Experiential Marketing yaitu sense, feel, think, dan act. Pada umumnya Relate Experience menunjukkan hubungan dengan orang lain, kelompok lain (misalnya negara, masyarakat, budaya). Tujuan dari Relate Experience adalah menghubungkan konsumen tersebut dengan budaya dan lingkungan sosial yang dicerminkan oleh merek suatu produk.

Hubungan pengalaman pelanggan terhadap kepercayaan pelanggan menurut

(Salim, Catherine dan Andreani M. M 2013) menyatakan bahwa "pengalaman pelanggan berpengaruh secara positif dan signifikan terhadap kepercayaan pelanggan".

\section{Kepercayaan Pelanggan}

Hubungan yang terjadi antara perusahaan dengan pelanggan banyak ditentukan oleh kepercayaan dan komitmen (Morgan dan Hunt, 1994). Sementara itu, menurut McKnight dalam Febri (2017) kepercayaan dibangun antara pihak-pihak yang belum saling mengenal baik dalam interaksi maupun proses transkasi. McKnight menyatakan bahwa ada dua dimensi kepercayaan konsumen, yaitu:

1. Trusting Belief. Trusting belief adalah kepercayaan terhadap suatu objek tertentu yang dimana objek tersebut memiliki karakteristik yang menguntungkan bagi pihak yang percaya (konsumen). McKnight dalam Febri (2017) menjelaskan secara rinci komponen-komponen trusting belief, yaitu:

2. Integrity (integritas) adalah kejujuran dan kemampuan penjual dalam menepati janji yang telah disepakati dan akan diberikan kepada konsumen. Integrity menunjukan suatu perilaku atau kebiasaan yang dimiliki penjual dalam menjalankan usahanya apakah informasi yang diberikan sesuai dengan fakta atau tidak.

3. Benevolence (niat baik) berarti perhatian dan motivasi untuk bertindak sesuai dengan kepentingan konsumen oleh penyedia barang. Kebaikan hati merupakan kemauan penjual dalam memberikan kepuasan yang saling menguntungkan antara dirinya dan 
konsumen. Penjual bukan semata-mata mengejar keuntungan melainkan juga memiliki perhatian yang besar dalam mewujudkan kepuasan konsumen.

4. Competence (kompetensi) adalah kemampuan penjual untuk melaksanakan kebutuhan dari konsumen. Dalam hal ini bagaimana penjua mampu menyediakan, melayani, sampai mengamankan transaksi dari gangguan pihak lain. Artinya bahwa konsumen memperoleh jaminan kepuasan dan keamanan dari penjual dalam melakukan transaksi.

Hubungan nilai pelanggan terhadap kepercayaan pelanggan (Febri, 2017) menyatakan bahwa, "nilai pelanggan berpengaruh secara positif dan signifikan terhadap kepercayaan pelanggan”. Hubungan pengalaman pelanggan terhadap kepercayaan pelanggan menurut (Salim, Catherine dan Andreani M, 2013) menyatakan bahwa pengalaman pelanggan berpengaruh secara positif dan signifikan terhadap kepercayaan pelanggan

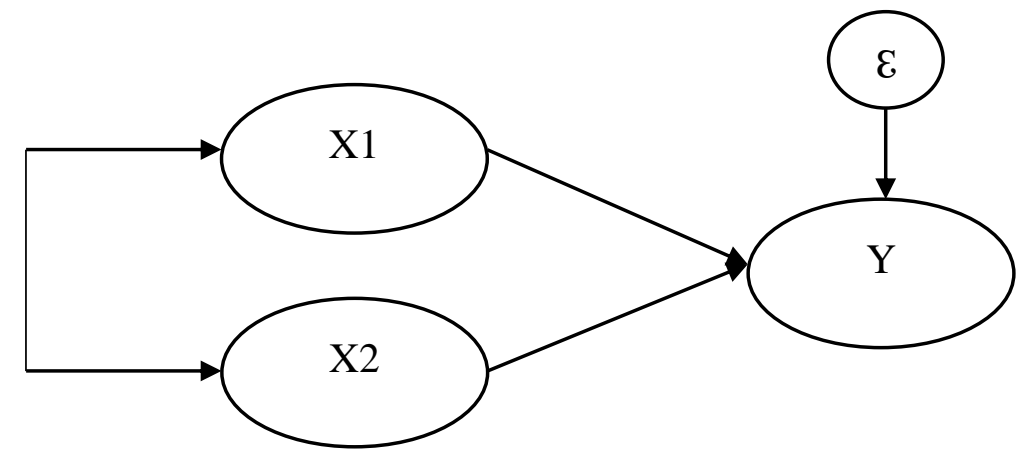

Gambar 1 Paradigma Penelitian

Keterangan :

Variabel X1 = Nilai Pelanggan

Variabel X2 = Pengalaman Pelanggan

Variabel Y = Kepercayaan Pelanggan

\section{METODE PENELITIAN}

Penelitian ini dilaksanakan di Wisata Kuliner Selamat Toserba Sukabumi dengan menggunakan metode sampling dengan teknik samplingnya yaitu simple random sampling dan melakukan penyebaran kuesioner terhadap 100 pelanggan Wisata Kuliner Selamat Toserba Sukabumi. Teknik analisis yang digunakan dalam penelitian 
ini yaitu teknik analisis regresi berganda dan melakukan pengujian hipotesis secara Simultan (Uji F) dan juga parsial (Uji t).

Adapun teknik penelitin yang digunakan dalam pengumpulan data penelitian ini yaitu: (1) observasi, yaitu dengan mendatangi tempat penelitian untuk memperoleh gambaran yang terjadi pada responden dengan masalah yang akan diteliti. (2) wawancara, teknik komunikasi secara langsung yang bertujuan untuk mendapat datadata yang dibutuhkan. (3) kuesioner, daftar pernyataan yang digunakan untuk memperoleh hasil penelitian terhadap variable yang di teliti.

Dalam penelitian ini menggunakan skala likert. Menurut Sugiyono (2010: 93) menyatakan bahwa "skala likert digunakan untuk mengukur sikap, pendapat dan persepsi seseorang atau sekelompok menyusun item - item instrumen yang berupa pernyataan". Instrumen pertanyaan atau pernyataan ini akan menghasilkan total skor dengan bobot nilai : (1) SS = Sangat setuju diberi skor 5. (2) S = Setuju diberi skor 4. (3) $\mathrm{CS}=$ Cukup Setuju diberi skor 3. (4) TS = Tidak setuju diberi skor 2. (5) STS = Sangat tidak setuju diberi skor 1 .

\section{HASIL PENELITIAN}

\section{Hasil Analisis Regresi Linear Berganda}

Regresi linear berganda berguna untuk meneliti seberapa besar pengaruh beberapa variabel yang berkorelasi dengan variabel yang diuji. Berikut ini merupakan hasil dari regresi linear berganda yang ditunjukan pada tabel 1 :

Tabel 1

Hasil Uji Regresi Linear Berganda

\begin{tabular}{|c|c|c|c|c|c|c|}
\hline \multicolumn{7}{|c|}{ Coefficients $^{a}$} \\
\hline \multirow{2}{*}{\multicolumn{2}{|c|}{ Model }} & \multicolumn{2}{|c|}{ Unstandardized Coefficients } & \multirow{2}{*}{$\begin{array}{c}\begin{array}{c}\text { Standardized } \\
\text { Coefficients }\end{array} \\
\text { Beta }\end{array}$} & \multirow[b]{2}{*}{$t$} & \multirow[b]{2}{*}{ Sig. } \\
\hline & & $\mathrm{B}$ & Std. Error & & & \\
\hline \multirow[t]{3}{*}{1} & (Constant) & 2.048 & 1.141 & & 1.795 & .076 \\
\hline & Nilai Pelanggan & .176 & .078 & .199 & 2.268 & .026 \\
\hline & Pengalaman Pelanggan & .340 & .055 & .546 & 6.223 & .000 \\
\hline
\end{tabular}

a. Dependent Variable: Kepercayaan Pelanggan

Dari hasil uji regresi linear berganda diatas, dapat diperoleh persamaan sebagai berikut :

$\mathrm{Y}=2.048+0,176 \mathrm{X}_{1}+0,340 \mathrm{X}_{2}$ 


\section{Koefisien Determinasi $\left(\mathbf{R}^{2}\right)$}

Tabel 2

Hasil Koefesien Determinasi

Model Summary

\begin{tabular}{|l|l|r|r|r|}
\hline Model & R & R Square & $\begin{array}{c}\text { Adjusted R } \\
\text { Square }\end{array}$ & $\begin{array}{c}\text { Std. Error of } \\
\text { the Estimate }\end{array}$ \\
\hline 1 & $.669^{\mathrm{a}}$ & .448 & .437 & 1.034 \\
\hline
\end{tabular}

a. Predictors: (Constant), Pengalaman Pelanggan, Nilai Pelanggan

Hasil tabel 2 menunjukan besarnya nilai Adjusted $\mathrm{R}^{2}$ adalah 0,437; Hal tersebut menunjukan $43,7 \%$ variabel kepercayaan pelanggan dapat dijelaskan oleh kedua variabel independen yaitu Nilai Pelanggan dan Pengalaman PelangganSementara $56,3 \%$ berasal dari faktor yang tidak diteliti dalam penelitian.

\section{Koefesien Korelasi Ganda (R)}

Tabel 3

Hasil Koefesien Korelasi Ganda

Model Summary

\begin{tabular}{|l|l|r|r|r|}
\hline Model & $\mathrm{R}$ & R Square & $\begin{array}{c}\text { Adjusted R } \\
\text { Square }\end{array}$ & $\begin{array}{c}\text { Std. Error of } \\
\text { the Estimate }\end{array}$ \\
\hline 1 & $.669^{\mathrm{a}}$ & .448 & .437 & 1.034 \\
\hline
\end{tabular}

a. Predictors: (Constant), Pengalaman Pelanggan, Nilai Pelanggan

Berdasarkan tabel 3 diatas diperoleh angka R Sebesar 0,669 berada pada kategori 0,60-0,799. Hal ini menunjukan bahwa terjadi hubungan yang kuat antara nilai pelanggan dan pengalaman pelanggan dengan kepercayaan pelanggan.

\section{Uji Signifikasi Secara Simultan (Uji F)}

Tabel 4

Hasil Uji F

\begin{tabular}{|c|c|c|c|c|c|c|}
\hline \multicolumn{7}{|c|}{ ANOVA ${ }^{a}$} \\
\hline \multicolumn{2}{|c|}{ Model } & $\begin{array}{c}\text { Sum of } \\
\text { Squares }\end{array}$ & df & Mean Square & $\mathrm{F}$ & Sig. \\
\hline \multirow[t]{3}{*}{1} & Regression & 84.148 & 2 & 42.074 & 39.377 & $.000^{\mathrm{b}}$ \\
\hline & Residual & 103.642 & 97 & 1.068 & & \\
\hline & Total & 187.790 & 99 & & & \\
\hline
\end{tabular}

a. Dependent Variable: Kepercayaan Pelanggan

b. Predictors: (Constant), Pengalaman Pelanggan, Nilai Pelanggan

Berdasarkan tabel 4 diatas, hasil uji $\mathrm{F}$ yang dilakukan dapat diperoleh nilai sig. $0,000<0,05$; nilai $F_{\text {hitung }} 39,377>F_{\text {tabel }} 2,36$. Hasil ini menunjukan bahwa nilai pelanggan 
dan pengalaman pelanggan berpengaruh secara simultan terhadap kepercayaan pelanggan.

\section{Uji Signifikasi Secara Parsial (Uji t)}

Tabel 5

Hasil Uji t

\begin{tabular}{|c|c|c|c|c|c|c|}
\hline \multicolumn{7}{|c|}{ Coefficients $^{a}$} \\
\hline \multirow{2}{*}{\multicolumn{2}{|c|}{ Model }} & \multicolumn{2}{|c|}{ Unstandardized Coefficients } & \multirow{2}{*}{$\begin{array}{c}\begin{array}{c}\text { Standardized } \\
\text { Coefficients }\end{array} \\
\text { Beta }\end{array}$} & \multirow[b]{2}{*}{$t$} & \multirow[b]{2}{*}{ Sig. } \\
\hline & & $\mathrm{B}$ & Std. Error & & & \\
\hline \multirow[t]{3}{*}{1} & (Constant) & 2.048 & 1.141 & & 1.795 & .076 \\
\hline & Nilai Pelanggan & .176 & .078 & .199 & 2.268 & .026 \\
\hline & Pengalaman Pelanggan & .340 & .055 & .546 & 6.223 & .000 \\
\hline
\end{tabular}

a. Dependent Variable: Kepercayaan Pelanggan

Berdasarkan tabel 5 diatas, hasil uji t yang dilakukan pada variabel nilai pelanggan menghasilkan nilai dengan sig. $0,000<0,05$; nilai $t_{\text {hitung }} 2,268>t_{\text {tabel }} 1,99346$, nilai tersebut menunjukan bahwa nilai pelanggan berpengaruh positif dan signifikan secara parsial terhadap kepercayaan pelanggan. Variabel pengalaman pelangganmemiliki nilai sig. $0,000<0,05$; nilai $\mathrm{t}_{\text {hitung }} 6,223>\mathrm{t}_{\text {tabel }} 1,29043$, artinya pengalaman pelangganberpengaruh positif dan signifikan terhadap kepercayaan pelanggan.

\section{PEMBAHASAN}

\section{Hasil Uji Hipotesis}

Nilai pelanggan berpengaruh secara positif dan signifikan terhadap kepercayaan pelanggan (Y) secara parsial. Hal ini berdasarkan hasil pengujian t yang menunjukan nilai sig. $0,000<0,05$; nilai $t_{\text {hitung }} 2,268>t_{\text {tabel }} 1,99346$, maka dapat disimpulkan bahwa $\mathrm{H}_{\mathrm{a}}$ diterima dan $\mathrm{H}_{0}$ ditolak. Hal ini menunjukan bahwa nilai pelanggan yang ada di Wisata Kuliner memberikan nilai positif dalam mempengaruhi kepercayaan pelanggan konsumen.

Pengalaman pelanggan berpengaruh secara positif dan signifikan terhadap kepercayaan pelanggan (Y) secara parsial. Hal ini dibuktikan dengan hasil pengujian $\mathrm{t}$ yang menunjukan nilai sig. $0,000<0,10$; nilai $t_{\text {hitung }} 6,223>\mathrm{t}_{\text {tabel }} 1,29043$, maka dapat disimpulkan bahwa $\mathrm{H}_{\mathrm{a}}$ diterima dan $\mathrm{H}_{0}$ ditolak. Hal ini menunjukan bahwa pengalaman 
pelangganyang dilakukan oleh sesama pelanggan memberikan nilai positif dalam mempengaruhi kepercayaan pelanggan lain.

Nilai pelanggan dan pengalaman pelangganberpengaruh positif dan signifikan terhadap kepercayaan pelanggan (Y) secara simultan. Hal ini dibuktikan dengan hasil pengujian $\mathrm{F}$ menunjukan nilai sig. $0,000<0,05$; nilai $\mathrm{F}_{\text {hitung }} 39,377>\mathrm{F}_{\text {tabel }} 2,36$, dari hasil tersebut dapat disimpulkan bahwa $\mathrm{H}_{\mathrm{a}}$ diterima dan $\mathrm{H}_{0}$ ditolak. Hal ini menunjukan bahwa nilai pelanggan dan pengalaman berpengaruh signifikan secara simultan terhadap kepercayaan pelanggan.

\section{Hasil Analisis Regresi Secara Simultan}

Berdasarkan dari hasil yang didapat melalui analisis regresi berganda uji $\mathrm{F}$ dengan tingkat signifikasi sebesar 0,10 (10\%) menunjukan bahwa variabel Nilai pelanggan $\left(\mathrm{X}_{1}\right)$ dan Pengalaman pelanggan $\left(\mathrm{X}_{2}\right)$ berpengaruh secara simultan terhadap Kepercayaan pelanggan (Y). Hal tersebut ditunjukan dengan hasil nilai sig. 0,000 $<0,05$ dan nilai $F_{\text {hitung }} 39,377>F_{\text {tabel }} 2,36$. Nilai Koefesien Determinasi $\left(R^{2}\right)$ diperoleh hasil yang menunjukan variabel Nilai pelanggan $\left(\mathrm{X}_{1}\right)$ dan Pengalaman pelanggan $\left(\mathrm{X}_{2}\right)$ mempengaruhi sebesar 0,437 (43,7\%) terhadap Kepercayaan pelanggan (Y), dan 56,3\% dipengaruhi oleh faktor yang tidak di teliti dalam penelitian. Dari hasil tersebut dapat disimpulkan bahwa pelanggan akan memutuskan membeli produk tersebut jika bentuk, rasa serta kualitas produk sesuai dengan harapan mereka. Selain itu pengalaman pelanggan sebelumnya serta kreatifitas dari penjual dalam membuat produknya memberikan kesan berbeda dari produk yang sama pada umumnya. Kepercayaan pelanggan juga mempengaruhi pelanggan lain dalam melakukan pembelian, rekomendasi dan juga ajakan dari orang lain terhadap produk tersebut membuat pelangganpercaya terhadap produk Wisata Kuliner Selamat Toserba Sukabumi.

\section{Pengaruh Nilai pelanggan $\left(\mathrm{X}_{1}\right)$ terhadap Kepercayaan pelanggan $(\mathrm{Y})$}

Berdasarkan hasil yang didapat melalui analisis data pada uji t Nilai pelanggan $\left(\mathrm{X}_{1}\right)$ dengan Kepercayaan pelanggan $(\mathrm{Y})$ menunjukan bahwa nilai $\mathrm{t}_{\text {hitung }}$ sebesar 2,268 sedangkan $\mathrm{t}_{\text {tabel }}(\alpha=0,10)$ diperoleh hasil $\mathrm{t}_{\text {tabel }} 1,99346$. Nilai signifikasi yang didapat $0,000<0,05$ dan nilai $t_{\text {hitung }} 2,268>t_{\text {tabel }} 1,99346$, maka pengaruh $\left(\mathrm{X}_{1}\right)$ terhadap $(\mathrm{Y})$ signifikan. Dari hasil tersebut dapat disimpulkan bahwa Nilai pelanggan berpengaruh 
secara signifikan terhadap Kepercayaan pelanggan. Hal ini menunjukan bahwa saat pelanggan membeli produk, Nilai pelanggan yang didapat melalui jika bentuk, rasa serta kualitas produk sesuai dengan harapan pelanggan menjadi alasan kepercayaan pelanggan terhadap produk Wisata Kuliner Selamat Toserba Sukabumi.

\section{Pengaruh Pengalaman pelanggan $\left(\mathrm{X}_{2}\right)$ terhadap Kepercayaan pelanggan ( $\left.\mathrm{Y}\right)$}

Berdasarkan hasil analisis yang dilakukan dengan menggunakan teknik uji t pada variabel Pengalaman pelanggan(X2) dengan Kepercayaan pelanggan (Y) menunjukan bahwa nilai $\mathrm{t}_{\text {hitung }}$ sebesar 6,223 sedangkan $\mathrm{t}_{\text {tabel }}(\alpha=0,10)$ diperoleh hasil ttabel 1,29043. Nilai signifikasi yang didapat $0,000<0,05$ dan nilai $t_{\text {hitung }} 6,223>$ $\mathrm{t}_{\text {tabel }}$ 1,29043, maka pengaruh (X2) terhadap (Y) signifikan. Dari hasil tersebut dapat disimpulkan bahwa pengalaman pelanggan berpengaruh secara signifikan terhadap kepercayaan pelanggan. Hal ini menunjukan bahwa pengalaman pelanggan sebelumnya serta kreatifitas dari penjual dalam membuat produknya memberikan kesan berbeda dari produk yang sama pada umumnya, selain itu hubungan antara penjual dan pelanggan juga mempengaruhi kepercayaan pelanggan pada produk Wisata Kuliner Selamat Toserba Sukabumi.

\section{SIMPULAN}

Nilai pelanggan dan Pengalaman pelanggan berpengaruh positif dan signifikan secara simultan terhadap Kepercayaan pelanggan pada Wisata Kuliner Selamat Toserba Sukabumi. Nilai pelanggan berpengaruh positif dan signifikan secara parsial terhadap Kepercayaan pelanggan pada Wisata Kuliner Selamat Toserba Sukabumi. Pengalaman pelangganberpengaruh positif dan signifikan secara parsial terhadap Kepercayaan pelanggan pada Wisata Kuliner Selamat Toserba Sukabumi.

\section{DAFTAR PUSTAKA}

Af Hami, Moch Lutfi Salis., Suharyono., dan Hidayat, Kadarisman, (2016), Analisis Pengaruh Nilai Pelanggan Terhadap Kepuasan Pelanggan dan Dampaknya Pada Loyalitas Pelanggan, Jurnal Administrasi Bisnis (JAB) 39(1):10-25

Febri, Nisrina Nur, (2017), Pengaruh Kualitas Pelayanan, Customer Value, dan Citra Perusahaan Terhadap Kepercayaan Serta Dampaknya Kepada Kepuasan Nasabah BANK SYARIAH MANDIRI, Skripsi. 
Guenzi, Paolo., Johnson, Michael D., Castaldo, Sandro (2009), A comprehensive model ofcustomer trust in two retail stores, Institute of Marketing, Department of Management,SDA Bocconi School of Management, Bocconi University, Milan, Italy and School of Hotel Administration, Cornell University,Ithaca, New York, USA.

Kristiana, Yustisia., Suryadi, Michael Thomas., Sunarya, Samuel Riyandi (2018), Eksplorasi Potensi Wisata Kuliner Untuk Pengembangan Pariwisata Di Kota Tangerang, Jurnal Khasanah Ilmu, 9(1):80-90

Morgan, R. dan S. Hunt, 1994, The Commitment-Trust Theory of Relationship Marketing, Journal of Marketing, 58(1), 20-38.

Mustika, Gina Anggina dan Andari, Rini, (2015), Pengaruh Customer Value Terhadap Keputusan Menggunakan Meeting Package Di Golden Flower Hotel Bandung, Tourism and Hospitality Essentials (THE) Journal, 1(1),30-40

Perepelkin,Jason., Zhang, David (2011), Brand personality and customer trust in community pharmacies, International Journal of Pharmaceutical and Healthcare Marketing, 5 (3), 175-193.

Rahmi, Mildayani., Andari, Rini., dan Yuniawati, Yeni (2016), Pengaruh Customer Experience Terhadap Behavioral Intention Wisatawan di Saung Angklung Udjo, Tourism and Hospitality Essentials (THE) Journal, 6(2), 20-30

Ribbink, Dina., Riel, Allard C.R. van., Liljander., Veronica., and Streukens,Sandra (2004), Comfort your online customer: quality, trust and loyalty on the internet, Managing Service, 14, (6), 446-456.

Robinette, Scott \& Claire Brand, (2001), Emotion Marketing, Me Graw Hill

Salim, KennyFebrina., Catherine., dan Andreani, Dra.Fransisca M.M, (2013), Pengaruh Customer Experience Dan Kepercayaan Terhadap Keputusan Konsumen Di TX TRAVEL KLAMPIS, Program Studi Manajemen Perhotelan, Universitas Kristen Petra. https://81184-ID-pengaruh-customer-experience-dankeperca.pdf.

Tjiptono, Fandy. (2014). Pemasaran Jasa. In Yogyakarta: Andi. 